\title{
Phenotypic Characterization of Listeria ivanovii in Sheep in Jammu Region of Jammu and Kashmir, India
}

\author{
Moien Javaid* and Mohd. Rashid
}

Division of Veterinary Public Health and Epidemiology, F.V.Sc \& A.H., R.S.Pura, Jammu, SKUAST-J, India

*Corresponding author

\section{A B S T R A C T}

\begin{tabular}{|l|}
\hline K e y w o r d s \\
$\begin{array}{l}\text { Feacal samples, CAMP } \\
\text { test, Listeria ivanovii, } \\
\text { phosphatidylinositol- } \\
\text { specific phospholipase C, } \\
\text { Sheep }\end{array}$ \\
\hline Article Info \\
\hline $\begin{array}{l}\text { Accepted: } \\
\text { 30 January } 2018 \\
\text { Available Online: } \\
\text { 10 March } 2018\end{array}$ \\
\hline
\end{tabular}

\section{Introduction}

Listeria ivanovii is a Gram-positive and facultative intracellular pathogen. The genus Listeria contains fifteen species that are phylogenetically related (Schmid et al., 2005; den Bakker et al., 2014). The genus Listeria possesses 2 pathogenic species i.e., Listeria monocytogenes and Listeria ivanovii (Seeliger and Jones, 1986). Both of them invade host cells, replicate in the cytoplasm after phagosomal escape and spread from cell to cell by polymerizing protein called actin (Vázquez-Boland et al., 2001). While Listeria monocytogenes infects both man and animals, Listeria ivanovii is principally an animal pathogen that rarely occurs in man (Low and Donachie, 1997). Listeria ivanovii is considered to be highly specific to ruminants and is responsible for almost $15 \%$ of all animal listeriosis cases (McLauchlin, 1987). The major clinical manifestations of listeriosis due to Listeria ivanovii include enteritis, abortion and neonatal sepsis but there is no report of infection of (Ammendolia et al., 2007; Buchrieser et al., 2011). Human listeriosis cases involving Listeria ivanovii have been reported in susceptible individuals belonging to special groups at risk, such as persons of advanced age, cancer patients and AIDS patients (Guillet et al., 2010; Snapir et al., 2006). 
Prevalence of Listeria species from milk, meat, environmental samples vegetables and faeces have been reported by several authors (Ikeh et al., 2010; Atil et al., 2011; Yakubu et al., 2012; Abay et al., 2012; Brian et al., 2012). The presence of Listeria species in faeces was associated with its presence in feed (Buncic, 1991; Sanaa et al., 1993). Listeriosis is of major veterinary importance in cattle, sheep and goats (Low and Donache, 1997), because of large economical losses in livestock production through morbidity and high mortality and also with regard to food safety and public health representing a possible link between the environment and human infection.

There is paucity of data on the prevalence of Listeria ivanovii in sheep in Jammu, therefore the present study therefore aimed at There are paucity of information on the prevalence of Listeria species in ruminants in Maiduguri. The present study therefore aimed at characterisation and determination of the prevalence of Listeria ivanovii in sheep in Jammu region of Jammu and Kashmir.

\section{Materials and Methods}

\section{Isolation and identification of Listeria spp.}

\section{Collection of samples}

A total of 250 faecal samples of sheep ( 25 gm each) were collected in and around Jammu. All the collected samples were quickly transported to the laboratory under chilled and aseptic conditions. The samples were kept at $4^{\circ} \mathrm{C}$ in the laboratory and were analyzed within 24 hours of being in the laboratory.

\section{Processing of samples}

Isolation of Listeria spp. from the collected samples was attempted as per the United
States Department of Agriculture (USDA) method described by McClain and Lee (1988) after making necessary modifications.

\section{Selective Enrichment}

Two stage enrichment procedure comprised of primary enrichment followed by secondary enrichment described by McClain and Lee (1988) with modification was adopted. The samples obtained were mixed properly and then $1 \mathrm{gm}$ of sample was inoculated with $9 \mathrm{ml}$ of University of Vermont medium-I (UVM-I) and was incubated at $30^{\circ} \mathrm{C}$ for $24-36$ hours for primary enrichment. Enriched inoculum (0.1 $\mathrm{ml}$ ) from UVM-I was then transferred to $10 \mathrm{ml}$ of University of Vermont medium-II and incubated at $30^{\circ} \mathrm{C}$ for 48 hours for secondary enrichment.

\section{Plating on selective agar}

The inoculum $(0.1 \mathrm{ml})$ from UVM-II was streaked directly on Listeria Oxford medium base, modified and incubation at $30^{\circ} \mathrm{C}$ for 48 hours.

Presumptive Listeria spp. colonies of typical small, round greyish blackish colonies of about $0.5 \mathrm{~mm}$ diameter surrounded by a diffuse black zone of aesculin hydrolysis were picked up for identification and further characterization (2-5 from each plate).

\section{Purification and Identification}

\section{Purification}

Presumptive isolates were further purified on brain heart infusion (BHI) agar and identified according to Seeliger and Jones (1986) and Holt et al., (1994). The isolates were examined for their morphology, Gram's reaction and motility on Motility Test Medium (semi- solid agar tubes) at $20-25^{\circ} \mathrm{C}$ (Knabel et al., 1990). 


\section{Biochemical tests}

The purified isolates were grown in BHI broth and subjected to different biochemical tests as described by Cruickshank et al., (1975) and Barrow and Feltham (1993).

\section{Catalase test}

The presumptive Listeria spp. isolates were tested for their catalase activity. A drop of 3 per cent hydrogen peroxide (H2O2) was mixed with the presumed colony using a platinum loop. The formation of gas bubbles was taken as positive reaction.

\section{Oxidase test}

A loopful of bacterial growth was rubbed using a sterile platinum loop on oxidase disc (Hi Media Ltd., Mumbai) in a sterile Petri plate. Development of deep purple blue or mauve colour within $10 \mathrm{sec}$ was considered as positive and no change in the colour was taken as negative reaction.

\section{Methyl Red test}

A loopful of culture was inoculated into two $\mathrm{ml}$ sterile glucose phosphate peptone water (Hi Media Ltd.) and incubated for $48 \mathrm{hrs}$ at $37^{\circ} \mathrm{C}$. Subsequently, 5 drops of methyl red indicator were added. A positive reaction was indicated by the development of bright red colour at junction and negative reaction by yellow colour.

\section{Voges-Proskauer test}

In a tube containing $2 \mathrm{ml}$ of sterile glucose phosphate peptone water (Hi Media Ltd., Mumbai) a loopful of young broth culture (18$24 \mathrm{~h}$ ) was inoculated followed by incubation at $37^{\circ} \mathrm{C}$ for $48 \mathrm{hrs}$. After $48 \mathrm{hrs}, 0.2 \mathrm{ml}$ potassium hydroxide was added followed by $0.2 \mathrm{ml}$ of $\alpha$-napthol solution and the tube was shaken vigorously. The cotton plugs were removed and the tubes were left in an inclined position for an hour at room temperature. The development of pink or crimson colour was recorded as positive reaction while no colour change revealed the negative reaction.

\section{Nitrate reduction test}

Sterile nitrate broth (Hi Media Ltd.) $0.5 \mathrm{ml}$ was inoculated with a heavy growth of the test organism and incubated at $37^{\circ} \mathrm{C}$ for $24 \mathrm{hrs}$. Subsequently, one drop each of sulphanilic acid and the $\alpha$-naphthylamine reagent was added to the test culture in broth. The development of red colour within one minute was taken as positive reaction. The tube that did not show red colour within five minutes was treated with zinc powder $(5 \mathrm{mg} / \mathrm{ml}$ of culture) and allowed to stand for $5 \mathrm{~min}$. In such cases, the development of red colour indicated the presence of nitrate in the medium, as it was not reduced to nitrite by the test organism.

\section{Sugar fermentation tests}

All the presumptive Listeria isolates were tested for mannitol, L- rhamnose, D- xylose and $\alpha$-methyl D-mannoside fermentation patterns as per the method of Cruickshank et al., (1975) and Barrow and Feltham (1993). A loopful of culture was inoculated into $5 \mathrm{ml}$ sterile peptone water with 1 per cent Andrade's indicator or methyl red indicator (Hi Media Ltd., Mumbai) and incubated for 48 hrs at $37^{\circ} \mathrm{C}$. After $48 \mathrm{hrs}$ change in colour and gas production was noted.

\section{Haemolysis on sheep blood agar (SBA)}

All the biochemically characterized Listeria spp. isolates were tested for the type and the degree of haemolysis on SBA. The isolates were streaked onto SBA plates and incubated at $37^{\circ} \mathrm{C}$ in a humidified chamber for $24 \mathrm{hrs}$ 
and examined for haemolytic zones around the colonies.

\section{Christie, Atkins, Munch-Peterson (CAMP)} test

All the haemolytic Listeria spp. isolates were tested by CAMP test as per the method of BIS (1994) with some modifications. Briefly, the standard strain of Staphylococcus aureus ( $S$. aureus) (MTCC 1144) and Rhodococcus equi (R.equi) (MTCC 1135) were grown overnight on sheep blood agar (SBA) plates at $37^{\circ} \mathrm{C}$ and one colonies of each were again streaked onto freshly prepared SBA plates in a manner that these were wide apart and parallel to each other. Subsequently, the Listeria isolates were streaked onto these plates at $90^{\circ}$ angle and 3 $\mathrm{mm}$ apart from $S$. aureus and $R$. equi strains and incubated at $37^{\circ} \mathrm{C}$ for $24 \mathrm{hrs}$.

\section{Phosphatidylinositol-specific phospholipase C (PI-PLC assay)}

All the suspected Listeria ivanovii isolates were assayed for PI-PLC activity as per the method of Notermans et al., (1991b). The Listeria isolates were grown overnight onto L. mono Confirmatory Agar Base with Listeria mono Selective Supplement I \& II and Listeria mono Enrichment Supplement II at $35-37^{\circ} \mathrm{C}$.

\section{Results and Discussion}

On Listeria modified Oxford medium base, typical small, round greyish blackish colonies of about $0.5 \mathrm{~mm}$ diameter surrounded by diffuse black zone of aesculin hydrolysis presumed to be Listeria species were observed in case of 10 samples. The typical colonies (with diffuse black zone of aesculin hydrolysis) of Listeria spp. were examined morphologically for Gram positive coccobacilli. Gram-positive, small rods present in singles and as diplo-forms producing $\mathrm{V}$ or $\mathrm{Y}$ shapes and arranged parallel to one another representing a palisade arrangement were observed on gram staining in the same 10 samples showing typical colony characteristics.

\section{Biochemical tests}

A set of biochemical tests was applied on all the 10 morphologically characterized Listeria spp. isolates. All of these 10 isolates showed the typical pattern (Seeliger and Jones, 1986) of biochemical tests of Listeria spp. (Table 1). Out of these 10 Listeria spp. isolates 2 isolates showed no acid production with L- rhamnose, a-methyl D-mannoside and Mannitol but showed acid production with D-xylose, which is the characteristic feature of Listeria ivanovii (Seeliger and Jones, 1986).

\section{Haemolysis on Sheep blood agar (SBA)}

All the biochemically characterized Listeria spp. isolates $(n=10)$ were streaked on $5 \%$ Sheep Blood Agar (SBA) and observed for haemolytic changes for $24-48$ hours at $37^{\circ} \mathrm{C}$ and out of them 9 Listeria spp. isolates showed haemolysis and one isolate was non haemolytic. It must be taken into account that the characteristic $\square$-haemolysis in the form of wider and clear zone of haemolysis represents Listeria ivanovii while a narrow zone of $\square$ haemolysis is the characteristic of Listeria monocytogenes. A typical $\beta$-haemolysis with a well-defined clear zone of haemolysis was present in 2 isolates, thus confirming them to be Listeria ivanovii. The pathogenic strains of Listeria ivanovii are essentially hemolytic, and the spontaneous loss of hemolysin production has been observed to result in loss of the virulence (Hof, 1984). Therefore, haemolysis is an important characteristic, which seems to be directly related to the pathogenicity of Listeria spp. since non-hemolytic Listeria species are practically considered as nonpathogenic (Courtieu, 1991). 
Table.1 Biochemical characteristics of phenotypically characterized isolates of Listeria species

\begin{tabular}{|l|c|}
\hline Biochemical test & Result \\
\hline Catalase & + \\
\hline Oxidase & - \\
\hline MR & + \\
\hline VP & + \\
\hline Urea & - \\
\hline Nitrate & - \\
\hline
\end{tabular}

Listeria ivanovii also secretes two cytolytic factors, one is a thiol-activated haemolysin of $61 \mathrm{kDa}$ termed as ivanolysin O (ILO), and the other is a $27 \mathrm{kDa}$ sphingomylinase $\mathrm{C}$ found to be involved in the activity of the CAMP factor (Vazquez-Boland et al., 1989).). A thiol-activated haemolysin called ivanolysin $\mathrm{O}$ (ILO), is produced by all the virulent strains of Listeria ivanovii, whereas, non-ILO producing strains are avirulent (Low, 1990; Kovassi and Shelef, 1995). Since our two isolates exhibited clear and wider zones of haemolysis, so there is possibility that they can be pathogenic in nature.

\section{Christie, Atkins, Munch-Peterson (CAMP) test}

A total of 9 haemolytic isolates as obtained through haemolysis on SBA, were subjected to CAMP test with Staphylococcus aureus (MTCC 1144) and Rodococcus equi (MTCC 1135).

A total of 2 haemolytic isolates showed enhancement of haemolytic zone with Rhodococcus equi but there was no haemolytic zone with $S$. aureus and were thus characterized as Listeria ivanovii.

Based on the results of biochemical tests, sugar fermentations tests, haemolysis on 5\% SBA and CAMP test, 2 isolates of Listeria spp. exhibited characteristic features of Listeria ivanovii, thus these two isolates were characterized as Listeria ivanovii.

\section{Prevalence of Listeria ivanovii}

Out of 250 sheep faecal samples, 10 isolates of Listeria spp. were obtained. Thus the prevalence of Listeria spp. was $4 \%$. Out of these 10 Listeria spp. isolates, two isolates of were characterized as Listeria ivanovii, thus giving the prevalence of $0.8 \%$.

\section{Phosphatidylinositol-specific phospholipase C (PI-PLC assay)}

A phosphatidylinositol-specific phospholipase $\mathrm{C}$ (PI-PLC) is an important determinant of pathogenicity in both Listeria monocytogenes and Listeria ivanovii and has been found to be a reliable marker for discrimination between pathogenic and non-pathogenic Listeria species (Notermans et al., 1991a). PI-PLC of Listeria spp., a protein secreted in the active state (Marquis et al., 1997) is encoded by plcA gene.

Phospholipase C enzyme produced by virulent Listeria monocytogenes and Listeria ivanovii hydrolyses the phosphatidylinositol substrate added to the medium and results in the formation of an opaque halo around the colonies (Notermans et al., 1991b). The supplements also contain $\square$-Methyl Dmannoside, whose fermentation by Listeria monocytogenes produce yellow coloured colonies while Listeria ivanovii cannot ferment this sugar so the colonies are purple coloured. Out of 2 Listeria ivanovii isolates only one was positive for PI-PLC assay and 
exhibit an opaque halo around the puple coloured colonies. So, a total of one pathogenic isolate of Listeria ivanovii was obtained from 250 faecal samples of sheep, thus showing the prevalence of $0.4 \%$ of pathogenic Listeria ivanovii in sheep in Jammu.

\section{Acknowledgements}

The authors acknowledge SKUAST- Jammu for the technical and financial assistance in carrying out this study.

\section{References}

Abay, S., Aydin, F. and Sumerkan A.B. 2012. Molecular typing of Listeria spp. Isolated from different sources. Ankara Üniv Vet FakDerg., 59: 183-190.

Ammendolia, M.G., Superti, F., Bertuccini, L., Chiarini, F., Conte, M.P., et al., 2007. Invasive pathway of Listeria ivanovii in human amnion-derived WISH cells. Int J Immunopathol Pharmacol., 20: 509-518.

Atil, H., Ertas, H.B. and Ozbey, G. 2011. Isolation and molecular characterization of Listeria spp. from animals, food and environmental samples. Vet. Med., 56 (8): 386-394.

Barrow, G.I. and Feltham, R.K.A. 1993. Cowan and Steel's Manual for the Identification of Medical Bacteria. 3rd edn. Cambridge University Press, Cambridge. pp 140-143.

Brian, D.S., Jon, O., Esther, F., Katy, W., Ynte, S., Arthur, L. and Martin, W. 2012. Diversity of Listeria Species in Urban and Natural Environments. Appl. Environ. Microbiol., 78 (12):4420-4433.

Buchrieser, C., Rusniok, C., Garrido, P., Hain, T., Scortti, M., et al., 2011 Complete genome sequence of the animal pathogen Listeria ivanovii, which provides insights into host specificities and evolution of the genus Listeria. J. Bacteriol., 193: 6787-6788.

Buncic, S. 1991. The Incidence of Listeria monocytogenes in Slaughtered Animals, in Meat and in Meat Products in Yugoslavia. Int. J. Food Microbiol, 12: 173-180.
Courteiu, A. L. 1991. Latest news on Listeriosis. Comparative Immunology, Microbiology and Infectious Diseases, 14:1-7.

Cruickshank, R., Duguid, J. P., Marimon, B. P. and Swain, B. P. 1975. Medical Microbiology, $12^{\text {th }}$ edition, Churchill Livingstone, Edinburgh, London.

Den Bakker, H.C, Warchocki, S., Wright, E.M., Allred, A.F., Ahlstrom, C., et al., 2014 Listeria floridensis sp. nov., Listeria aquatica sp. nov., Listeria cornellensis sp. nov., Listeria riparia sp. nov. and Listeria grandensis sp. nov., from agricultural and natural environments. Int. J. Syst. Evol. Microbiol., 164: 1882- 1889.

Guillet,.C, Join-Lambert, O., Le Monnier, A., Leclercq, A., Mechai, F., et al., 2010. Human listeriosis caused by Listeria ivanovii. Emerg. Infect. Dis., 16: 136-138.

Hof, H. 1984. Virulence of different strains of Listeria monocytogenes serovar $1 / 2 \mathrm{a}$. Med. Microbiol. Immunol., 173: 207-218

Holt, J. G., Krieg, N. R., Sneath, P.H. A., Staley, J. T. and Williams, S. T. 1994. Bergey's Manual of Determinative Bacteriology, 9th edition, Williams and Wilkins, Baltimore. pp. 566-570.

Ikeh, M.A.C., Obi, S.K.C., Ezeasor, D.N., Ezeonu, I.M. and Moneke, A.N. 2010. Incidence and pathogenicity profile of Listeria sp. isolated from food environmental samples in Nsukka, Nigeria. Afr. J. Biotechnol., 9(30): 4776-4782.

Knabel, S. J., Walker, H. W., Hartman, P. A. and Mendonca, A. F. 1990. Effects of Growth Temperature and Strictly Anaerobic Recovery on the Survival of Listeria monocytogenes during Pasteurization. Appl. Environ. Microbiol., 56(2): 370-379.

Kovassi, N. M. and Shelef, L. A. 1995. Listeriolysin $\mathrm{O}$ secretion by Listeria monocytogenes in the presence of cysteine and sorbate. Lett. Appl. Microbiol., 20: 295-299.

Low, J.C. and Donachie, W. 1997. A review of Listeria monocytogenes and listeriosis. Vet. J., 153(1):9-29.

Low, M.G. 1990. Degradation of glycosylphophatidylinositol anchors by specific phospholipases, p. 35-63. In A.J. Turner (ed.), Molecular and cell biology of 
membrane proteins. Glycolipid anchors of cell surface proteins. E. howard Ltd., Chichester, England.

Marquis, H., Goldfine, H. and Portnoy, D.A. 1997. Proteolytic pathways of activation and degradation of a bacterial phospholipase $\mathrm{C}$ during intracellular infection by Listeria monocytogenes. J. Cell Biol., 137: 1381-1392.

McClain, D. and Lee, W. H. 1988. Development of USDA-FSIS method for isolation of Listeria monocytogenes from raw meat and poultry. J. Asoc. Off.l Anal. Chem., 71: 660-664.

McLauchlin, J.1987 Listeria monocytogenes, recent advances in the taxonomy and epidemiology of listeriosis in humans. J. Appl. Bacteriol., 63: 1-11.

Notermans, S., Dufrenne, J., Chakraborty, T., Steinmeyer, S. and Terplant, G. (1991a). The chick embryo test agrees with the mouse bio-assay for assessment of the pathogenicity of Listeria species. Lett. Appl. Microbiol., 13: 161-164.

Notermans, S.H.W., Dufrenne, J., LeimeisterWachter, M., Domann, E. and Chakraborty, T. (1991b). Phosphatidylinositol-specific phospholipase $\mathrm{C}$ activity as a marker to distinguish between pathogenic and nonpathogenic Listeria species. Appl. Environ. Microbiol, 57: 2666-2670.

Sanaa, M, Poutrel, B., Menard, J.L. and Serieys, F. 1993. Risk Factors Asso-ciated with Contamination of Raw Milk by Listeria monocytogenes in Dairy Farms. J. Dairy Sci., 76: 2891- 2898.
Schmid, M.W., Ng, E.Y., Lampidis, R., Emmerth, M., Walcher, M., et al., 2005. Evolutionary history of the genus Listeria and its virulence genes. Syst. Appl. Microbiol., 28: $1-18$.

Seeliger, H.P.R. and Jones, D. 1986. Genus Listeria. In: Sneath, P.H.A., Mair, N.S., Sharpe, M.E. and Holt, J.G. editors. Bergey's manual of systematic bacteriology, Vol. 2. Baltimore: Williams \& Wilkins; p. 1235-1245.

Snapir, Y.M., Vaisbein, E. and Nassar, F. 2006. Low virulence but potentially fatal outcome-Listeria ivanovii. Eur. J. Intern. Med., 17: 286-287.

Vázquez-Boland, J.A., Dominguez, L., Rodriguez-Ferri, E.F. and Suarez, G. 1989. Purification and characterization of two Listeria ivanovii cytolysins, a sphingomyelinase $\mathrm{C}$ and a thiol-activated toxin (ivanolysin $\mathrm{O}$ ). Infect. Imm., 57: 3928-3935.

Vázquez-Boland, J.A., Kuhn, M., Berche, P., Chakraborty, T., Domínguez- Bernal, G., Goebel, W., et al., 2001. Listeria pathogenesis and molecular virulence determinants. Clin. Microbiol. Rev. 14:584-640.

Yakubu, Y., Salihu, M.D., Faleke, O.O., Abubakar, M.B., Junaidu, A.U., Magaji, A.A., Gulumbe, M.L. and Aliyu, R.M. 2012. Prevalence and antibiotic susceptibility of Listeria monocytogenesin raw milk from cattle herds within Sokoto Metropolis, Nigeria. Sokoto. J. Vet. Sci., 10(2):13 - 17 .

\section{How to cite this article:}

Moien Javaid and Mohd. Rashid. 2018. Phenotypic Characterization of Listeria ivanovii in Sheep in Jammu Region of Jammu and Kashmir, India. Int.J.Curr.Microbiol.App.Sci. 7(03): 3762-3768. doi: https://doi.org/10.20546/ijcmas.2018.703.435 